\title{
The Use of the Effective Vocabulary, Grammar and Function of English by the Biology Teachers
}

\author{
Ima Herminingsih, Dwi \\ Universitas Tulungagung, Mangun Sarkoro Beji, Tulungagung, East Java, Indonesia \\ Tel: 62-355-320396 E-mail: kampusunita@yahoo.com
}

Received: July 2, 2015 Accepted: November 2, 2015 Published: November 5, 2015

doi:10.5296/ijele.v3i2.8533 URL: http://dx.doi.org/10.5296/ijele.v3i2.8:533

\begin{abstract}
This research investigated vocabulary, grammar and function of English which could work well as a means of conducting: 1) the application of instruction (students' physical behaviors, giving orders or tasks), 2) the science instruction (imparting theories, the concepts, facts and information) and 3) vocabulary instruction (helping the students understand vocabulary). The research found three kinds of word used by the teachers namely: 1) High Frequency General Words, 2) Non Specialized Academic Words and 3) the Specialized Content Area Words. The category 1) were used for social function to build interpersonal communications, direct the students' physical behaviors and give the orders or the tasks. The category (2) and (3) were used in the area of academic function specifically to conduct the science instruction (explanations, descriptions, comparisons, assessments, clarifications, paraphrasing, directing instructions, and behaviors). Four sentence patterns (declarative, interrogative, imperative and exclamatory) were used for the application of instruction such as greetings, leave-takings, appreciating the students' works, directing the students' behaviors and the students to do the tasks. In the context of science instruction, the declaratives were used for explanations, descriptions, comparisons, clarifications and paraphrasing. Assessing the students' knowledge and doing the clarifications used interrogative sentences. The imperative sentences were used for directing the instructions and the students' behaviors. The exclamatory sentences were used to express the teachers' excitements, admirations or angers. The Noun-Phrase patterns with past-tense and non-past tense and its transformational forms were employed.
\end{abstract}

Keywords: effective, vocabulary, grammar, function, English 


\section{Introduction}

Using English as instructional language for Mathematics and Science was applied by a Junior High School labeled as a bilingual school in Indonesia in 2010. Linguistically, the use of English in the teaching and learning context such as the teacher talks, learning material was believed to be an English language modality to enrich the students' knowledge of grammar, vocabulary and language functions. Besides, classroom activities like a peer feedback, group discussion, questioning, answering, arguing, describing things, writing laboratory reports function as a language exposure as well a a medium to use English in real context. In this view, the teachers are strongly obliged to be competent in using an effective instructional to avoid sacrificing the students'understanding of content. The teachers' English competence could be measured by their possession of vocabulary, grammar and ability to use these two anguage components appropriately to its functions for the teaching instructional proposes.

\section{Objectives of the Research}

The study was intended to explain the linguistic aspecst of English covering:

a. The English Vocabularies which were used effectively by the Biology teachers to achieve the instructional purposes $s$ in certain contexts of instruction.

b. The English sentence patterns which were used effectively by the Biology teachers to achieve the instructional purposes in certain contexts of instruction.

c. The language function of English which was used effectively by the Biology teachers in certain application of instruction.

d. The language function of English which was used effectively by the Biology teachers in science instruction.

e. The language function of English which was used effectively by the Biology teachers in vocabulary instruction.

\section{Review of Related Literature}

\subsection{Communicative Competence}

Communicative competence is explained in different ways by experts. Hymes (1972) wrote communicative competence as an implicit and explicit knowledge of the rules of grammar and contextual or sociolinguistic knowledge of rules of language in context. He mentioned four aspects of communicative competence: what is formally possible, what is feasible, what is the social meaning or value of a given utterance, and what actually occurs. Canale and Swain (1980) defined communicative competence in the context of second language teaching. They synthesized communicative competence as a synthesis of knowledge of basic grammatical principles, knowledge of how language is used in social settings to perform communicative functions, and knowledge of how utterances and communicative functions can be combined according to the principles of discourse.

Canale and Swain (1980) classified communicative competence into grammatical 
competence, sociolinguistic competence, discourse competence, and strategic competence. Grammatical competence means the acquisition of phonological rules, morphological rules, syntactic rules, semantic rules and lexical items. Sociolinguistic competence refers to the learning of pragmatic aspect of various speech acts, namely, the cultural values, norms, and other socio-cultural conventions in social contexts. The speech acts include the context and topic of the discourse, the participants' social status, sex, and age, and other factors which influence styles and registers of speech. Since different situations call for different type of expressions as well as different beliefs, views, values, and attitudes, the development of sociolinguistic competence is essential for communicative social action. Discourse competence is the knowledge of rules regarding the cohesion (grammatical links) and coherence (appropriate combination of communicative functions of various types of discourse. Canale and Swain (1980) emphasized that sociolinguistic rules of use and rules of discourse are crucial in interpreting utterances for social meaning, particularly when the literal meaning of an utterance does not lead to the speaker's intention easily. Strategic competence is to do with the knowledge of verbal and nonverbal strategies to compensate for breakdowns such as self-correction and at the same time to enhance the effectiveness of communication such as recognizing discourse structure, activating background knowledge, contextual guessing, and tolerating ambiguity.

Gottieb (2006) identified that Academic Language proficiency centers on the delivery of understanding of an idea or message through one or more language domains; listening, speaking, reading, or writing. It generally involves three criteria: (1) comprehension and use of the specialized or technical vocabulary and language patterns associated with content, (2) linguistic of complexities of variety and length (phonology, syntax, and meaning), (3) demonstration of understanding or use of language system such as phonology, the grammatical structure, and the meaning of the language. Meanwhile, Stern (1983) claimed language proficiency as the actual performance of learner in a given language, it involves the mastery of (1) the form, (2) the linguistic, cognitive, affective and sociocultural meaning of those form, (3) the capacity to use the language with focus mainly on communication and attention to form. Language proficiency is associated with Communicative language ability involving linguistic proficiency and communicative proficiency.

Bachman (1990) argued language proficiency reflects how well one can use the rules of use of language and the rules of speaking in communication in specific situation setting purpose activities. Language Proficiency is individual's competence to use language or an expression of Students' linguistic knowledge and language use in four language domain, reading, writing, speaking, and listening in and outside school contexts and interactions. Cummins (1981) suggested two kinds of language ability that should be acquired when science taught in foreign language or second language. First, the science teacher has to have Basic Interpersonal Communication skills (BICS). BICS is needed in interpersonal relations or in informal situation. BICS is the day-to-day language needed socially with other people. The language can occur in the playground, lunch room, the school bus, sport area etc. Social Interactions are usually context embedded. They happen in a meaningful social context. They are not very demanding cognitively meaning that they are not dealing with synthesis, drawing 
conclusion, inferring. The language is not specialized. The language is face-to-face Conversations (verbal language), for instance, nonverbal features like gestures, body movement, and facial expressions all convey meaning and aid understanding. Due to contextual support, a second language is more easily acquired in this „context-embedded ${ }^{\text {ee }}$ situation. However, a student's good performance in BICS is not a predictor for her/his success in schools.

Second is cognitive academic language proficiency (CALP). Cummin (1981) defined CALP is a kind of language proficiency to make sense of and use academic language in less contextual situations. CALP is required in the classroom, where higher-order thinking skills (analysis, synthesis, evaluation, etc.) are involved, the language is frequently more formal, more Technical, more specialized, and more abstract „,disembodied ${ }^{\text {ee }}$ from a meaningful, supporting context. This ,context reduced ${ }^{e e}$ classroom communication (in listening, speaking, reading, and writing) would certainly pose more difficulty to students and teachers in acquiring language and literacy in English. Even if they have adequate literacy skills and strategies in Indonesian (top- down processing)- and these are transferable to English, still they are not sufficient conditions for a thorough comprehension of texts in English, for instance. Adequate knowledge of language and skills in English vocabulary, grammar and orthography are also necessary components for a full understanding.

\subsection{Language Functions}

There are over a hundred functional heading in English. In relation to an individual's need, for example, sociocultural language function is dominant. In the academic contexts, every teacher needs to communicate with the students. He/she needs a particular language function such as a personal, interpersonal, directive, referential, and imaginative. He/she learns to use language of expression of greeting, requesting, apologizing, questioning, and getting direction, giving information, like, dislike. (Halliday, 1973, Van Ek's, 1980 and Finocchiaro, 1983).

\section{Research Method}

The research employed qualitative method to identify the varieties of the Biology teachers' vocabulary, grammar and functions of English which could be understood by the second grade students of the Junior High School in Tulungagung, East Java Province, Indonesia during the process of teaching and learning. Method of collecting data used observation; interview and documentation. The obtained data were qualitatively analyzed with the procedure of data reduction, data display, drawing conclusions and data verification.

\section{The Research Findings}

Three categories of effective vocabulary that were used by the observed Biology teachers within three contexts of instructions can be elaborated in the following numbers: 1) High Frequency General Words (words that are used regularly in everyday context). For Examples: find, show, keep, help, speak, listen, get, cut, continue, decrease, advantage, disadvantage, live, can, do, draw, compare, continue, think, answer, question, need, choose, find, consist of, depend on, use, look at, change, completed, Whiteboard, ice, leaf, frog, tree, bottle, 
schoolyard, flies, ant, deer, buffalos, book, hand on activities, people, friend, bottle, group, grasshopper, destruction, forest, river, fish, quite, silent, cold, careful, small, diligent, big, small, large, fertile, high, tall, round, hot, fresh, rotten, extinct, particular, dense, moderate, clear, loud, slow, artificial, deep, quick, different, same, natural, unnecessary, necessary, ripe, difficult, easy, carefully, loudly, quickly, slowly, well, generally, everyday, next week, last week, few minutes, long time, socially, economically, culturally, specially, naturally, approximately, I, you, they, we, she, he, it, its, or, and, because, so, but, because, so, on the other hand, therefore, unlike, at, on, by, after, before, to, with, among, between, around, beside, above, about, over, for, in front of, back of, beside, or instance, Wow. Hi, fine, well, All right etc (2) Non Specialized Academic Words (words that are used across content area). For Examples : Examine, sample, cause, marine, human being, Sample organism, item, ecosystem, conservation, natural, controlled, fire, forest, context hunted, sustainable, exploitation, habitat, component, animal, estimate, community, niche, observe , interaction, individual, eat, get, population, sand, store, interrelated, consume, erosion, protect, survive, virus, the science bacteria, chemical, substance, function, kill, element, harmful, source, termites, produce, preserve, affect, density, food chain, provide, transfer, mineral, processes, human, organic, density, bacteria, biotic, boundary, solar, logging, legal, illegal, energy, and (3) Specialized Content Area Words (academic words unique to specific content area/conceptual terminology of science). For examples: mutualism pollen, biosphere, food chain etc within three contexts of instructions (application of instruction, science instruction and vocabulary instruction). The three mentioned categories of words were used in the domain of the social and the academic functions. In the domain of social function, High Frequency General Words were used to build interpersonal communication such as to direct the students ${ }^{\text {ee }}$ physical behaviors, to give the orders or the tasks, to greet, to express feelings wants, needs and to have leave-takings. In the domain of the academic function, Non Specialized Academic Words and Specialized Content Area Words were used for the purposes of explanations, descriptions, clarifications, comparisons, and assessments, paraphrasing in the contexts of application of instruction, science instruction and vocabulary instruction. Data of Specialized Content Area Words were unfrequently captured because the delivered teaching materials cover only two subtopics.

Four sentence patterns (the declaratives, the interrogatives, the imperatives and the exclamatory) were found effectively used within the three contexts of instructions. In the context of application of instruction, the Biology teachers found using those sentence patterns for greetings, leave-takings, appreciating the students' works, directing the students' behaviors, directing the students to do the tasks. In the context of science instruction, the declaratives were used for explanations, descriptions, comparisons, clarifications and paraphrasing. The interrogatives were used to assess the students "e knowledge and the clarifications. The question words began with "Which", "What", "Why", "Can", "May", and "To be ". The imperatives were used for directing the instructions and the students' behaviors. The exclamatory was used to express the Biology teachers' excitements, admirations or angers. The Biology teachers were observed using the Basic sentence pattern that consists of subject plus predicate. The subject was Noun-Phrase (NP). The predicate was Verb-Phrase (VP). A sentence transformation from the affirmatives to the interrogatives and the negatives 
were chosen for certain instructional purposes. The Biology teachers dominantly used simple sentences to avoid the students' misconceptions and misunderstandings. Complex sentences were only used if the ideas were not possible expressed using simple sentences.

The findings revealed the teachers used past tense and non-past tense (the simple present and future tenses). The non-past tense was used to refer to the facts, events that were not in the past. In the domain of social functions, the findings showed that no language supports appeared when the Biology teachers had to use High Frequency General Words, Non-Specialized Academic Words, and Specialized Academic within three contexts of instruction (application of instruction, science instruction and vocabulary instruction) for the personal conversations in the classroom. This situation happened because both the Biology teachers and the students could recognize the ordinary or non-academic meaning of general English. A different case happened when the Biology teachers had to use the academic words. The three Biology teachers were found using the scaffolding strategy to lower the abstractness, the uniqueness, the level of difficulty and the particularity of academic vocabulary. Several ways were taken by the three Biology teachers to avoid the students' misunderstandings. Three Biology teachers were observed struggling to solve their instructional problems. They helped the students get the meaning of the introducing academic words by employing certain instructional strategies. They did highlight the academic vocabulary in the subject they taught by using the language switching, doing translation from English to Indonesian, giving definitions, providing synonyms, examples, visuals, the real objects and doing repetitions, description and the explanation of science concepts to transfer the meaning of words to the students' understanding. Beside instructional strategies, figures were chosen as another alternative help to make the students understand science instruction. For example, when the students did not understand the explanation about the interaction happen between organisms in certain ecosystem and concept of parasitism, the Biology teachers were found providing the examples, simile and comparison. They applied also the general approaches of language teaching. They prepared glossary/list of words before starting a new lesson. In a certain case, Total Physical Response seemed to be also effectively used to instruct the vocabulary. The vocabulary instruction involved the students in a contextual learning. The Biology teachers asked the students do concrete experiences like doing the experiments in the live laboratory (in the yard and the garden) to communicate the meaning and help the students remember a wide range of extensive vocabulary.

In the domain of academic functions, three Biology teachers used English for the explanations, the descriptions, the comparisons, the assessments, and the clarifications and paraphrasing. These language functions were used within the application of instruction, the science instruction and the vocabulary instruction. In the context of application of instruction, the Biology teachers used the explanations and descriptions to direct the students do the tasks. In the context of science instruction and vocabulary instruction, the Biology teachers used the six integrated language functions. The explanations were used to indicate the scientific relationships, guide the students' understanding of the scientific concepts and gave the reasons for the scientific theories and the experiments. The explanations were also used to give the scientific reasons for theories and experiments. The descriptions are used to provide 
the students' background knowledge of the scientific concept. The descriptions were clarified by relating a real world and a science. The language function of comparisons were used to compare a new scientific theory, concept, or fact to another theory, concept, or fact that was understoodable to the students and the similarities and differences among two or more scientific theories, concepts, or facts. The language functions of clarifications were used to repair the students' misunderstanding of scientific concepts.

\section{Conclusions}

The research findings opened up the fact that English used by three observed Biology teachers worked effectively to conduct various instructions. Data gathered from the observations and interviews justified the evidence that the classroom interaction run well. The decision of three Biology teachers to choose the use of simple and ordinary English aid the students understand what the teachers instructed. This happened because the English used stood in the reach of the students'level English proficiency. The vocabulary, grammar of English they used confirmed the students'needs and content of subject. Hereby, the teachers'English was easy to understand. In addition, the English used by the teachers seemed appropriate to function of English that were demanded by the needs of application of instruction (directing students ${ }^{\text {ee }}$ physical behaviors, giving orders or tasks), the science instruction (imparting theories, the concepts, facts an information) and vocabulary instruction (helping the students understand vocabulary).

\section{Acknowledgement}

The research is completed to fulfill one of the requirements to obtain Doctoral Degree in the English Language Teaching Department, State University of Malang. My great gratitude is addressed to the Director of Graduate Program; Prof. Dr. I Nyoman Sudana Degeng, M.Pd and the chairperson of the English Language Teaching Program; Dr. Ariwijati W. Murdibjono, Dip. TESL, M.Pd who allowed me to take a seat for an examination, further to get board of examiners' approval for my Dissertation.

I also wish to thank many people whose supports and contributions to make this research possible. The Offices of Educational and Cultural Department in Tulungagung, Trenggalek, Blitar, Kediri, Ngawi, Madiun, and Pare who allowed me to get data that I need to support my research on the the use of the effective vocabulary, grammar and function of English by the Biology teachers of Junior High International Standard Schools in these districts (SMP RSBI) in the western area of East Java Province, Indonesia. My deepest thank, then, goes to my three wise and kindhearted advisors as well as language editors Prof. M. Adnan Latief, M.A., Ph.D, Dr. Arwijati W. Murdibjono, Dip.TESL, M.Pd, and Prof. Utami Widiati, M.A., Ph.D who have provided an excellent guidance, meaningful feedbacks, and constructive suggestions at various stages of this work.

\section{References}

Austin. John. L. (1962). How to Do Things with Words. Oxford: Charcudon Press. http://dx.doi.org/10.1093/acprof:oso/9780198245537.001.0001 


\section{Macrothink}

International Journal of English Language Education ISSN 2325-0887 2015, Vol. 3, No. 2

Bachman, L. F. (1990). Fundamental Consideration in Language Testing. Oxford: O.U.P. Performance. An Interim Study. Oxford: Pergamon Institute of English. http://dx.doi.org/10.2307/329499

Bailey, Alison L. Frances A. Butter, \& Christine Ong. (2004). Toward the Characterization of Academic Language in Upper Elementary Science Classrooms. Los Angeles: CRESS. University of California.

Balch, William S. (2006). Lectures on Language as Particularly with English Grammar. Barbara Tozier, Amy Cunningham: Bill Tozier.

John Flowerdew, Lindsay Miller. (1996). Lectures in a second language: Notes towards a cultural grammar. English for Specific Purposes Journal, 15(2), 121-140. http://dx.doi.org/10.1016/0889-4906(96)00001-4

Baker, C. (1998). Foundations of Bilingual Education and Bilingualism (2nd ed.). Clevedon: Multilingual Matters Ltd. http://dx.doi.org/10.1017/s0272263100012997

Baker, E., \& Jones, S. P. (1998). Encyclopedia of Bilingualism and Bülingual Education. Philadelphia: Multilingual Matters. http://dx.doi.org/10.1017/s004740450026404x

Bogdan, R.C., \& Biklen, S. K. (1998). Qualitative Research for Educatïon. London: Allyn and Bacon. http://dx.doi.org/10.1177/109821408200300407

Britinton, D. M. et. Al. (1989). Content-Based Second Language Instruction. Boston: Heinle \& Heinle Publishers. http://dx.doi.org/10.1093/oxfordhb/9780195384253.013.0019

Brown, H. D. (1987). Principles of Language Learning and Teaching. New Jersey: Prentice-Hall, Inc., Englewood Cliffs. http://dx.doi.org/10.1017/s027226310000752x

Brown, Douglass. H. (2004). Language Assessment: Principles and Classroom Practices. Longman: San Francisco state University. http://dx.doi.org/10.1177/0265532207086784

Bialystock, E. (1987a). Influences of Bilingualism on Metalinguistic Development. Second Language Research, 3(2), 154-166. http://dx.doi.org/10.1177/026765838700300205

Canale, M. (1983). From Communicative Competence to Communicative Language Pedagogy in Richard, J. C. \& Schmidt, R. W. (Eds), Language Communication, 2-27. London: Longman Heaton.

$\begin{array}{llll}\text { Cambridge International Dictionary } & \text { (2010). }\end{array}$ http://dx.doi.org/10.1016/s0346-251x(97)88216-4

Chamot, A. U., \& O'Mally, J. M. (1994). The CALLA Handbook: Implementing the Cognitive Academic Language Learning Approach. Reading, MA: Addison-Wesley.

Cheong, Lee Kok, Ngoh Geok Lun, and Arthur Yap. (1986). English Grammar and Usage. Singapore: Federal Publication Ltd. http://dx.doi.org/10.1016/s0346-251x(97)88216-4

Cloud, N. Genessee, F., and Hamayan, E. (2000). Dual Language Instruction. A way for Enriched Education. Boston: MA, Heinle and Heinle Thomson Learning. 
http://dx.doi.org/10.1075/jicb.2.1.09hoo

Collier, V. P., \& Thomas, W. P. (2008). The Astounding Effectiveness of Dual Language Education for All. NABE Journal of Research and Practice, 2(1), 1-20, (Online), (http://njrp.tamu.edu/2004/PDFs/Collier.pdf) retrieved July 2, 2010.

Crandal, J., \& Tucker, G. R. (1990). Content-Based Language Instruction in Second and Foreign Language in S. Anivan (Ed.), Language Teaching Methodology for the Nineties. Singapore: SEAMEO Regional Language Centre. http://dx.doi.org/10.4324/9780203836507.ch37

Cummins, J. (1976a). The Influences of Bilingualism a Cognitive Growth: Synthesis of Research Explanatory Hypothesis. Writing Paper and Bilingual,. 1-43. http://dx.doi.org/10.1080/13670050.2010.488282

Cummins, J. (1981). The Role of Primary Language Development in Promoting Educational Success for Language Minority Students. In Schooling and language Minority Students: A theoretical framework. Los Angeles: California State University, Evaluation, Dissemination, and Assessment Center. CAIS Conference: San Francisco, CA - March 18, 2007.

Cummins, J. (1992). Language Proficiency, Bilingualism and Academic Achievement in P.A. Richard-Amato and M.A. Snow (Eds.), 58-70. The Multicultural Classroom: Reading for Content Area Teachers. White Plains, NY: Longman.

DEPDIKNAS. (2006). Pengembangan dan Pembelajaran SBI di SMP. Jakarta: Direktorat Jenderal Pendidikan Dasar Dan Menengah: Direktorat Pembinaan Sekolah Menengah Pertama.

Department of National Education. (2007). Science Module for Junior High School- Years 7 International Standard School. Jakarta: Directorate of Junior High School Development.

Directorate General of Primary and Secondary Education Management. (2006). Sistem Penyeleggaraan Sekolah Bertaraf International (SBI) Untuk Pendidikan Dasar dan Menengah. Jakarta: Departemen Pendidikan Nasional Direktorat Jenderal Pendidikan Dasar dan Menengah.

Directorate General of Junior High School Management. (2007 (b)). Panduan Penyelenggaraan Rintisan Sekolah Bertaraf International Untuk Sekolah Menengah pertama. Jakarta: Department of National Education.

de Courcy, M., Warren, J., \& Burston, M.( 2002). Children from Diverse Backgrounds in an Immersion Programme. Language and Education, 16(2), 112-127. http://dx.doi.org/10.1080/09500780208666823

Dwijayanti, E. (2008). The use of English in the Mathematic Teaching and Learning of the International Standard Class at SMPN I Malang. Unpublished Thesis. Malang: State University of Malang.

Ellis, Road. (1994). The Study of Second Language Acquisition. New York: Oxford 
University Press. http://dx.doi.org/10.1017/s0272263100014479

Fardhani, Aan Erlyana. (2012). The Development of English Test for Junior High School Mathematics Teachers of Rintisan Sekolah Bertaraf International (RSBI). Unpublished Dissertation. Malang: State University of Malang.

Fillmore, Lily Wong and Catherine E. Sow. (2000). What Teachers Need to Know about Language. ERIC Clearinghouse on Languages and Linguistics. http://dx.doi.org/10.1016/j.system.2004.02.006

Finocchiaro, M., \& Brumfit, C. (1983). The Functional-Notional Approach. http://dx.doi.org/10.2307/3586697

Salisbury. Fradd, S. H., \& Lee, O. (1998). Understanding the Specialized Languages of Mathematics and Science. Center for the Study of Language and Education: The George Washington UniversityWashington. 9-10. http://dx.doi.org/10.1037/e302642005-001

Fradd, S. H., \& Lee, O. (1999). Teachers' Roles in Promoting Science Inquiry with Students from Diverse Language Backgrounds. Educational Researcher, 28(6), 14-20. http://dx.doi.org/10.2307/1177292

Fromkin, David Blair and Peter Collins. (2000). An Introduction to Language. Australia: Harcourt Publisher international. http://dx.doi.org/10.2307/413657

Gass, S. M., \& Selinker, L. (1994). Second language Acquisition: An Introductory Course. New Jersey: Lawrence Erlbaum Associates. http://dx.doi.org/10.1017/s0272263100013802

Genesee, F. (1987). Learning through Two Languages: Studies of Immersion and Bilingual Education. Rowley, MA: Newbury House. http://dx.doi.org/10.2307/3587516

Genesse, F. (1994). Integrating Language and Content: Lesson from Immersion. Educational Practice Report. No 11, (Online), (<http:/www.nebe.gwu/misepups/ncrdsll/epr//htm $>$ ), retrieved on July 8, 2010.

Gottieb, M. (2006). Assessing English Language Learners: Bridge from Language Proficiency to Academic Achievement. Thousand oak: Corwin Press SAGE Publication Company. http://dx.doi.org/10.1080/19313150802668264

Gottieb, M., Cranley, M. E., and Camilleri, A. (2008). Understanding the WIDA English Language Proficiency Standards: a Resources Guide.2007 Edition. The University of Winconsin :www.wida.us. http://dx.doi.org/10.1080/0958822940070107

Halliday, M.A.K. (1977). Exploration in the Function of Language. New York: Elsevier. North- Holland.

Halliday, M.A.K. (1978). Language in Social Semiotic. Battimore: University Park Press.

Harmer, Jeremy. (1983). The Practice of English Language Teaching. New York: Longman Inc. Henderson, J., \& Wellington, J. 1998. Lowering the Language Barrier in Learning and Teaching Science. School Science Review, 79(288), 35-46. 


\section{Macrothink}

International Journal of English Language Education

ISSN 2325-0887

2015, Vol. 3, No. 2

Huda, N. (1997). A National Strategy in Achieving English Communicative Ability. The Journal of Education, 4, Special Edition, 281-292.

Holmes, J. (1998). Introduction to Sociolinguistics. London: Longman. http://dx.doi.org/10.1017/s0047404500018066

Hymes, D. (1972). "On Communicative Competence" in Pride, J and Holmes J (Eds.), Sociolinguistics. Harmondsworth: Penguin.

Ibrahim, Yusuf. (2001). The Implementation of EMI in Indonesia Universities: Its Opportunities, its Threats, its Problems and its Possible Solutions. Jurusan Sastra Inggris, Fakultas Sastra, Universitas Kristen Petra. (Online), (http://puslit.petra.ac.id/journals/letters), retrieved May 22, 2010.

Ismuninggar, Lina. (2009). English as a Medium of Instruction in the International Laboratory Primary School of Universitas Negeri Malang (UM). Unpublished Undergraduate Thesis. Malang: State University of Malang.

Johnson, Robert Keith, \& Merrill Swain. (1977). Immersion Education: International Perspectives. New York: Cambridge University Press. http://dx.doi.org/10.1017/cbo9781139524667

Jarret. D. (1999). The Inclusive Classroom: Teaching Mathematics and Science to English Language Learners. Oregon: Northwest Regional Educational Laboratory.

Jawa Pos. 22 Februari (2009). Tiga Tahun Pelaksanaan Rintisan Sekolah Bertaraf International.

Jawa Pos. 4 Januari (2012). Program RSBI Gagal Total.

Jawa Pos. 5 Januri (2012). Nuh: RSBI Jalan Terus.

Kim, Tina Lim Swee. (2007). Language Development Strategies for the Teaching of Science in English. SEAME, (Online) http:// rec sam.ed.my, retrieved June 3, 2010.

Kacakulah, Sabrim., Evrim Ustunluoglu,and Aysel.( 2005). The Effect of Teaching in Native and Foreign Language on Students' Conceptual Understanding in Science Courses. Asia-Pacific Forum on Science Learning and Teaching. Vol.6. Issue2, Article 2.

Krashen, S. D. (1982).Principles and Practice in Second Language Acquisition: New York: Pergamon. http://dx.doi.org/10.2307/328293

Krashen, S. D. (1987).Principles and Practice in Second Language Acquisition.Toronto : Prentice- Hall International. http://dx.doi.org/10.2307/3586656

Krashen, S. D., \& Terril, T. D. (1983). The Natural Approach: Language Acquisition In the Classroom. Oxford: Pergamon. http://dx.doi.org/10.1017/s0272263100005659

Lambert, W. E., \& Tucker, G. R. (1972). The Bilingual Education of Children: The St. Lambert experiment. Rowley, MA: Newbury House. http://dx.doi.org/10.2307/3585680 
Law of National System of Education No.20/2003. (SISDIKNAS) 2005. Jakarta: Cemerlang.

Lee, O., \& Fradd. (1994). Science for All, Including Students for Non English Background. Educational Research, 27(3), 12-21, (Online), (http://rer.sagepub.com/cgi/sciene/76/4/492), retrieved on May 20, 2010. http://dx.doi.org/10.3102/0013189x027004012

Lemke, J. (1990). Talking science: Language, Learning, and Values. Norwood, NJ: Ablex. http://dx.doi.org/10.1017/s0047404500015074

Marsh, D. (2006). English as a Medium of Instruction in the New Global Linguistic order: Global Characteristics, Local Consequences, (Online), METSMAC. (http:/www.info.gove.hk.in/moi/pdf), retrieved on May 10, 2010.

Marsh, D. (2006). Using Languages to Learn and Learning to Use Languages, (0nline), TIECLIL, (Online), (http:/www..ecml.at/clil matrix/luk.pdf, retrieved on June 20, 2010.

Mathematic and Science Education Center. (2006). Understanding of Specialized languages of Mathematics and Science, (Online), ( http:// www.wre 1.or/msec.pdf), retrieved November 14, 2010.

Metropolis. 9 Oktober (2010). Kwalitas Guru RSBI Masih Rendah.

Mile, M. B., \& Huberman, A. M. (1984). Qualitative Data Analysis. California: Sage Publication, Inc. http://dx.doi.org/10.1177/002076409704300109

Musthafa, B. (2001).Communicative Language Teaching in Indonesia: Issues of Theoretical Assumptions and Challenges in Classroom Practice. Journal of Southeast Asian Education, 2001, Vol. 2, 2: 296-308.

Mohammed, M., \& Nordin Azis. Impact on the Implementation of Bilingualism in Science and Mathematic Teaching in Malaysian School System, (Online), (http./search.msn.com./result.asp 22 q=using English in teaching science \& first $1 \&$ form $=$ Perl), retrieved November 11, 2008.

Noraini, Loh Sau Cheong, Ahmad Zabininbin Abdul Razak. (2006). Effective Teaching of Mathematics and Science in English: A case Study. Journal. Pendidikan Universiti Malaya, (Online), (Myais.fskm.um.ed.my/5352/1/8, retrieved June 2, 2009.

Nugrahani, A. (2008). The Teaching of English at SMP Negeri I Malang. A Case Study. Unpublished Thesis. Malang: State University of Malang.

O'Toole, John, \& David Becket. (2010). Educational Research: Creative Thinking \& Doing.

Victoria, Australia: Oxford University Press.

Peraturan Menteri pendidikan Nasional Republik Indonesia No 16 Tahun 2007 tentang Stadard Kualifikasi Akademik Kompetensi Guru. 2007. Jakarta: Badan Standard Nasional Pendidikan (BSNP).

Prajarisma, P. (2009). The Implementation of the Use of English in Physic Instruction at SMP RSBI Negeri 5 Malang. Unpublished thesis. Malang: State University of Malang. 


\section{Macrothink}

International Journal of English Language Education

ISSN 2325-0887

2015, Vol. 3, No. 2

Rachmajanti, S. R., Sulistyo, G. H, Utami W. (2008). Pengembangan Paket Model Pembelajaran Bilingual Berbasis Pendekatan Kontekstual Berbentuk Compact Disc (CD). Unpublished. Hibah Bersaing Research Report. Malang : State University of Malang.

Rahman. ( 2005). Teachers'Competency in Teaching of Mathematics in English in Malaysian Secondary Schools, (online), (http./math.Unipa.it/grim/21malasya Rahman), retrieved on November 29, 2008. Rosenthal, J.W. 1996. Teaching Science to Language Minority Students. England: Multilingual Matters Ltd.

Semiun, A. (2009). The Use of English as a Medium of Instruction by Senior-High School EFL Teachers in NTT. Unpublished Dissertation. Malang: State University of Malang.

Smolicz, Nical, I., Secombe, M. (2006). English as the Medium of Instruction for Science ands Its Effects on the Language of Philippines. TESOL, (Online), (TESOL\%20EJ\%202006\%20as\%20Med\%20), retrieved on May14, 2008. http://dx.doi.org/10.1515/9783110869484.205

Spolsky, B. (1989). Communicative Competence, Language Proficiency, and Beyond. Applied Linguistic, 2(2), 138-156. http://dx.doi.org/10.1093/applin/10.2.138

Spradley, James P. (1980). Participant Observation. New York: Holt, Rinehart and Winston. Supriyatna (supriyatna@yahoo.com.) 4 June 2009. English as a Medium of Instruction in International Classes. E-mail to Ima (dwima2008@yahoo.com). http://dx.doi.org/10.2307/3318111

Swain, M., \& Johnson, R. K. (1997). Immersion education: A Category within Bilingual Education. In R. K. Johnson \& M. Swain (Eds.), Immersion Education: International Perspectives. Cambridge: Cambridge University Press. http://dx.doi.org/10.1017/cbo9781139524667.003

Swain, M., \& Lapkin, S. (1982). Evaluating Bilingual Education: A Canadian case study. Clevedon, England: Multilingual Matters. http://dx.doi.org/10.1017/s0272263100005593

Tan, Peter, K. W. (2005). The Medium of Instruction Debate in Malysia. Language Problem and Language planning, 29(1), 47-66. http://dx.doi.org/10.1075/lplp.29.1.04tan

"Teacher Support". (2006). Let's talk, (Online), ( http://www.Cambridge. Org/us/esl/lets talk/support/language.htm.), retrieved April 8, 2010.

Thomas, W., \& Collier, V. (2002). A National Study of School Effectiveness for Minority Language Students' Long Term Academic Achievement. Washington, DC: National. Clearinghouse for Bilingual Education. Santa Cruz, CA: Center for Research on Education, Diversity, and Excellence.

TOEIC (a). The TOEIC Speaking and Writing Test, (Online), (http://www.examenglish.com/TOEIC/toeic speaking and reading.htm.), retrieved on August 22, 2010. http://dx.doi.org/10.4307/jsee.61.4_49 


\section{Macrothink}

International Journal of English Language Education

ISSN 2325-0887 2015, Vol. 3, No. 2

TOEIC (b). The TOEIC Speaking and Writing Test, (Online), http://dx.doi.org/10.1002/j.2333-8504.2009.tb02175.x

(http://www.examenglish.com/TOEIC/toeic speaking and reading.htm.), retrieved on August 22, 2010. Undang-Undang RI No.20 Tahun 2003 Tentang Sistem Pendidikan Nasional (SISDIKNAS). 2005. Jakarta: Cemerlang.

UNESCO. (2007). Mother Tongue Matters: Local Language as a Key to effective Learning France: UNESCO Division or the Promotion of Basic Education Sector. http://dx.doi.org/10.1163/ej.9789004164543.1-0

Universitas Negeri Malang. (2007). Pedoman Penulisan Karya Ilmiah. Malang: Universitas Negeri Malang.

Van.Ek. J. A. (1980). The Threshold Level for Modern Language Learning in Shools. Oxford: Pergamon Press. http://dx.doi.org/10.1093/elt/34.3.232-a

Vygotskij, Lev S. (1985). Thought and Language. Cambridge: MIT Press.cop. http://dx.doi.org/10.1017/s0272263100008172

Wellington, J., \& Osborne, J. (2001). Language and Literacy in Science Education. Philadelphia, P.A.: Open University Press.

Widdowson, A. G. (1983). Learning Purpose and Language Use. Oxford: Oxford University Press.

\section{Copyright Disclaimer}

Copyright for this article is retained by the author(s), with first publication rights granted to the journal.

This is an open-access article distributed under the terms and conditions of the Creative Commons Attribution license (http://creativecommons.org/licenses/by/3.0/). 